reveals a new slow-acetylator allele common in AfricanAmericans. Carcinogenesis 1993; 14: 1689-1692.

6 Brockmoller J, Gross D, Kerb R, Drakoulis N, Roots I: Correlation between trans-stilbene oxide-glutathione conjugation activity and the deletion mutation in the glutathione $S$-transferase class $\mathrm{mu}$ gene detected by polymerase chain reaction. Biochem Pharmacol 1992; 43: 647-650.

7 de Morais SM, Wilkinson GR, Blaisdell J, Nakamura K, Meyer UA, Goldstein JA: The major genetic defect responsible for the polymorphism of $S$-mephenytoin metabolism in humans. J Biol Chem 1994; 269: 15419-15422.

8 Gaedigk A, Gotschall RR, Forbes NS, Simon SD, Kearns GL, Leeder JS: Optimization of cytochrome P4502D6 (CYP2D6) phenotype assignment using a genotyping algorithm based on allele frequency data. Pharmacogenetics 1999; 9: 669-682.

9 Pemble S, Schroeder KR, Spencer SR et al: Human glutathione $S$-transferase theta (GSTT1): cDNA cloning and the characterization of a genetic polymorphism. Biochem J 1994; 300 (Part 1): $271-276$.

10 Rotger M, Colombo S, Furrer $\mathrm{H}$ et al: Influence of CYP2B6 polymorphism on plasma and intracellular concentrations and toxicity of efavirenz and nevirapine in HIV-infected patients. Pharmacogenet Genomics 2005; 15: 1-5.

11 Cavalli-Sforza LL: The Human Genome Diversity Project: past, present and future. Nat Rev Genet 2005; 6: 333-340.

12 Rosenberg NA, Pritchard JK, Weber JL et al: Genetic structure of human populations. Science 2002; 298: 2381-2385.

13 Agyemang C, Bhopal R, Bruijnzeels M: Negro, Black, Black African, African Caribbean, African American or what? Labelling African origin populations in the health arena in the 21st century. J Epidemiol Community Health 2005; 59: 1014-1018.
14 Ely B, Wilson JL, Jackson F, Jackson BA: African-American mitochondrial DNAs often match mtDNAs found in multiple African ethnic groups. BMC Biol 2006; 4: 34.

15 Sirugo G, Schim vdL, Sam O et al: A national DNA bank in the Gambia, West Africa, and genomic research in developing countries. Nat Genet 2004; 36: 785-786.

16 Kaiser J: Genomic medicine. African-American population biobank proposed. Science 2003; 300: 1485.

17 Klein K, Lang T, Saussele T et al: Genetic variability of CYP2B6 in populations of African and Asian origin: allele frequencies, novel functional variants, and possible implications for anti-HIV therapy with efavirenz. Pharmacogenet Genomics 2005; 15: 861-873.

18 Nolan D, Phillips E, Mallal S: Efavirenz and CYP2B6 polymorphism: implications for drug toxicity and resistance. Clin Infect Dis 2006; 42: 408-410.

19 Rodriguez-Novoa S, Barreiro P, Jimenez-Nacher I, Soriano V: Overview of the pharmacogenetics of HIV therapy. Pharmacogenomics J 2006; 6: 234-245.

20 Masimirembwa C, Persson I, Bertilsson L, Hasler J, Ingelman-Sundberg M: A novel mutant variant of the CYP2D6 gene (CYP2D6*17) common in a black African population: association with diminished debrisoquine hydroxylase activity. Br J Clin Pharmacol 1996; 42: 713-719.

21 Kirchheiner J, Brosen K, Dahl ML et al: CYP2D6 and CYP2C19 genotype-based dose recommendations for antidepressants: a first step towards subpopulation-specific dosages. Acta Psychiatr Scand 2001; 104: 173-192.

22 Masimirembwa CM, Hasler JA: Genetic polymorphism of drug metabolising enzymes in African populations: implications for the use of neuroleptics and antidepressants. Brain Res Bull 1997; 44: $561-571$.

Supplementary Information accompanies the paper on European Journal of Human Genetics website (http://www.nature.com/ejhg)

\section{Maternal genotype effects can alias case genotype effects in case-control studies}

European Journal of Human Genetics (2008) 16, 783-785; doi:10.1038/ejhg.2008.74; published online 9 April 2008;

With the increasing popularity of case-control association studies in human genetics, it is worth recalling that other genetic mechanisms may masquerade as case genotype effects. In particular, in a case-control study, any maternal genotype effects are aliased with case genotype effects. The maternal genotype partially determines the uterine environment, leading to the possibility of detrimental effects in the developing fetus. Such maternal genotype effects have been implicated in developmental disorders, such as spina bifida and autism. ${ }^{1-4}$ Maternal-fetal interactions are a separate phenomenon not discussed here. ${ }^{5}$
When an allele contributes to susceptibility only in the mother, the offspring will be enriched for that allele simply by Mendelian inheritance. At a locus with two alleles A and a, with frequencies $p$ and $q=1-p$, respectively, let $r_{1}^{\mathrm{m}}$ be the relative risk of disease given a single copy of $\mathrm{A}$ in the mother and $r_{2}^{\mathrm{m}}$ the relative risk of disease given two copies of A in the mother. Writing $D_{\mathrm{c}}$ for 'disorder present in the child,' $M$ for the number of copies of the $A$ allele in the mother, and $C$ for the number of copies of the A allele in the child, we have

$$
\begin{aligned}
P\left(D_{c} \mid C=j\right) & =\sum_{i} P\left(D_{c} \mid M=i, C=j\right) P(M=i \mid C=j) \\
& =\sum_{i} P\left(D_{c} \mid M=i\right) P(M=i \mid C=j) \\
& =b \sum_{i} r_{i}^{m} P(M=i \mid C=j)
\end{aligned}
$$

where $b$ is the prevalence of the disorder among offspring with mothers with genotype aa and $r_{0}^{\mathrm{m}}=1$. The conditional frequencies, under Hardy-Weinberg equilibrium, of the mothers' genotypes can be easily calculated ${ }^{6}$ but are given in Table 1 for easy reference.

By way of example, suppose $p=0.1, r_{2}^{\mathrm{m}}=2$, and $r_{1}^{\mathrm{m}}=1.5$. For an aa child, by Table 1, the probability of an Aa mother 
Table 1 Conditional probability of mother's genotype given child's genotype

\begin{tabular}{llll}
\hline & \multicolumn{3}{l}{ Probability } \\
& $A A$ & $A a$ & $A a$ \\
\hline Given: child AA & $p$ & $q$ & 0 \\
Given: child Aa & $p / 2$ & $1 / 2$ & $q / 2$ \\
Given: child aa & 0 & $p$ & $q$ \\
\hline
\end{tabular}

Table 2 Apparent relative risks

\begin{tabular}{|c|c|c|}
\hline & Maternal effect & \\
\hline Parameter & $\begin{array}{l}\text { Analysis of cases } \\
\text { versus controls }\end{array}$ & $\begin{array}{l}\text { Analysis of mothers } \\
\text { of cases versus }\end{array}$ \\
\hline $\begin{array}{l}\text { Apparent relative } \\
\text { risk of } \mathrm{Aa}\end{array}$ & $\frac{1+r_{1}^{\mathrm{m}}+p\left(r_{2}^{\mathrm{m}}-1\right)}{2+2 p\left(r_{1}^{\mathrm{m}}-1\right)}$ & \\
\hline \multirow[t]{2}{*}{$\begin{array}{l}\text { Apparent relative } \\
\text { risk of AA }\end{array}$} & $\frac{r_{1}^{\mathrm{m}}+p\left(r_{2}^{\mathrm{m}}-r_{1}^{\mathrm{m}}\right)}{1+p\left(r_{1}^{\mathrm{m}}-1\right)}$ & $r_{2}^{m}$ \\
\hline & Case effect & \\
\hline Parameter & $\begin{array}{l}\text { Analysis of cases } \\
\text { versus controls }\end{array}$ & $\begin{array}{l}\text { Analysis of mothers } \\
\text { of cases versus } \\
\text { mothers of controls }\end{array}$ \\
\hline $\begin{array}{l}\text { Apparent relative } \\
\text { risk of } \mathrm{Aa}\end{array}$ & $r_{1}^{c}$ & $\frac{1+r_{1}^{c}+p\left(r_{2}^{c}-1\right)}{2+2 p\left(r_{1}^{c}-1\right)}$ \\
\hline $\begin{array}{l}\text { Apparent relative } \\
\text { risk of } A A\end{array}$ & $r_{2}^{c}$ & $\frac{r_{1}^{c}+p\left(r_{2}^{c}-r_{1}^{c}\right)}{1+p\left(r_{1}^{c}-1\right)}$ \\
\hline & \multicolumn{2}{|c|}{ Maternal imprinting effect } \\
\hline Parameter & $\begin{array}{l}\text { Analysis of cases } \\
\text { versus controls }\end{array}$ & $\begin{array}{l}\text { Analysis of mothers } \\
\text { of cases versus } \\
\text { mothers of controls }\end{array}$ \\
\hline $\begin{array}{l}\text { Apparent relative } \\
\text { risk of } A a\end{array}$ & $\left(r^{j}+1\right) / 2$ & $\left(r^{i}+1\right) / 2$ \\
\hline $\begin{array}{l}\text { Apparent relative } \\
\text { risk of } A A\end{array}$ & $r^{j}$ & $r^{j}$ \\
\hline
\end{tabular}

is $p=0.1$ and the probability of an aa mother is $q=0.9$. The Aa mother gives an elevated risk of 1.5 times baseline to her child, whereas the aa mother gives the baseline risk to her child. Thus an aa child has $0.1 \times 1.5+0.9 \times 1=1.05$ times the baseline risk. Similarly, an AA child has an AA mother with probability 0.1 and an Aa mother with probability 0.9, so that child's risk is $0.1 \times 2+0.9 \times 1.5=1.55$ times the baseline risk. Thus, the apparent relative risk of an AA child relative to an aa child is $1.55 / 1.05=1.48$. For an Aa child, the probability of an AA mother is 0.05, that of an Aa mother 0.5 , and that of an aa mother is 0.45 , so an Aa child's risk is $0.05 \times 2+0.5 \times 1.5+0.45 \times 1=1.3$ times baseline, with apparent relative risk (relative to an aa child) equal to $1.3 / 1.05=1.24$. As this example illustrates, the apparent risk for the case's genotype will be attenuated from the actual risk for the mother's genotype. General expressions for relative risks based on the formula above and Table 1 are given in the upper panel of Table 2 .

Even the mode of inheritance can be masked: a recessive model in mothers (so that $r_{1}^{\mathrm{m}}=1$ ) will appear to be additive in the cases, with the apparent relative risk of AA equal to $1+p\left(r_{2}^{\mathrm{m}}-1\right)$ and the apparent relative risk of Aa equal to $1+p\left(r_{2}^{\mathrm{m}}-1\right) / 2$. Similarly, a multiplicative model in mothers, with $r_{2}^{\mathrm{m}}=\left(r_{1}^{\mathrm{m}}\right)^{2}$, will generate an apparently additive model in cases with the apparent case relative risk of AA equal to $1+\left(r_{1}^{\mathrm{m}}-1\right)$ and of Aa equal to $1+\left(r_{1}^{\mathrm{m}}-1\right) / 2$.

It is important to note that these apparent relative risks will reappear in a replication study; they are a function of the underlying biology and the study design, not an artifact of chance. Unlike the effects of population stratification on the results of a case-control design, the aliasing of maternal and case-genetic effects cannot be resolved by more refined statistical techniques. The use of family designs, however, can allow maternal and case effects to be distinguished. ${ }^{7-9}$ The log-linear test, ${ }^{7}$ in particular, can be used with a case-parents design to estimate maternal effects independently of case effects, as well as allowing a test of parental imprinting.

A 'mothers of cases' and controls study also cannot distinguish between maternal effects and case effects. Table 2 shows the apparent relative risks for mothers when there is a case genotype effect based on similar calculations as above. For completeness, the table also shows the apparent relative risks for mothers when there is a maternal imprinting effect on cases.

Although family-based designs offer excellent robustness to population stratification, they cost more per case than case-control designs and involve more difficult ascertainment. For example, among the six studies in the Genetic Association Information Network, ${ }^{10}$ one is a family-based design. Thus just one of these high-profile genome-wide association studies can distinguish the effects on cases due to the maternal genotype, by the uterine environment, from the direct effects of genotype on the cases. The vast preponderance of genes can be expected to act directly in subjects. However, until the biological mechanism of a suspected causal variant is determined, given only casecontrol association studies, we must recall that a statistical association is only an association. In addition to confounders, such as population stratification, there is the question of whether the statistical association of a disorder is really with one's genotype or with one's mother's 
genotype. A family-based association study can give a direct answer.

\section{Competing interests}

The author declares no competing financial interests.

Steven Buyske*,1,2

${ }^{1}$ Department of Statistics, Rutgers University, Piscataway,

NJ, USA;

${ }^{2}$ Department of Genetics, Rutgers University, Piscataway,

NJ, USA

*Correspondence: Professor S Buyske, Department of Statistics, Rutgers University, Hill Center, 110 Frelinghuysen Road, Piscataway, NJ 08854, USA.

E-mail: buyske@stat.rutgers.edu

\section{References}

1 Doolin M-T, Barbaux S, McDonnell M, Hoess K, Whitehead AS, Mitchell LE: Maternal genetic effects, exerted by genes involved in homocysteine remethylation, influence the risk of spina bifida. Am J Hum Genet 2002; 71: 1222-1226.

2 Jensen LE, Etheredge AJ, Brown KS, Mitchell LE, Whitehead AS: Maternal genotype for the monocyte chemoattractant protein 1
A(-2518)G promoter polymorphism is associated with the risk of spina bifida in offspring. Am J Med Genet A 2006; 140: $1114-1118$.

3 Williams TA, Mars AE, Buyske SG et al.: Risk of autistic disorder in affected offspring of mothers with a glutathione S-transferase P1 haplotype. Arch Pediatr Adolesc Med 2007; 161: 356-361.

4 Johnson WG: Teratogenic alleles and neurodevelopmental disorders. Bioessays 2003; 25: 464-477.

5 Hsieh H-J, Palmer CG, Harney $\mathrm{S}$ et al.: The v-MFG test: investigating maternal, offspring and maternal-fetal genetic incompatibility effects on disease and viability. Genet Epidemiol 2006; 30: 333-347.

$6 \mathrm{Li} \mathrm{CC}$, Sacks L: The derivation of joint distribution and correlation between relatives by the use of stochastic matrices. Biometrics 1954; 10: 347-360.

7 Weinberg CR, Wilcox AJ, Lie RT: A log-linear approach to case-parent-triad data: assessing effects of disease genes that act either directly or through maternal effects and that may be subject to parental imprinting. Am J Hum Genet 1998; 62: 969-978.

8 Mitchell LE, Weinberg CR: Evaluation of offspring and maternal genetic effects on disease risk using a family-based approach: the 'pent' design. Am J Epidemiol 2005; 162: 676-685.

9 Gjessing HK, Lie RT: Case-parent triads: estimating single- and double-dose effects of fetal and maternal disease gene haplotypes. Ann Hum Genet 2006; 70: 382-396.

10 Manolio TA, Rodriguez LL, Brooks L, et al., GAIN Collaborative Research Group: New models of collaboration in genome-wide association studies: the Genetic Association Information Network. Nat Genet 2007; 39: 1045-1051. 